Микола Бевз

Завідувач Кафедрою Архітектури та реставрачії, НУ,,Львівська політехніка”

Професор, Кафедра Консервації Пам'яток, Люблінська Політехніка email: bevzmist@polynet.lviv.ua

ORCID 0000-0003-1513-7045

Олександр Кишлярук

Аспірант, Національний університет «Львівська політехніка»

email: arka-s@i.ua

ORCID 0000-0001-5455-4824

\title{
FORTIFICATION OBIECTS AND STREET NETWORK DEVELOPMENT IN THE HISTORICAL PART OF CHERNIVTSI CITY IN THE $18^{\text {th }}-20^{\text {th }}$ CENTURIES
}

\author{
ФОРТИФІКАЦИЙНІ ОБ'ЄКТИ ТА РОЗВИТОК ВУЛИЧНОЇ МЕРЕЖІ \\ IСТОРИЧНОЇ ЧАСТИНИ МІСТА ЧЕРНІВЦІВ У XVIII -XX СТ.
}

(C) Бевз М., Кишлярук О., 2020

Анотація. Формування та розвиток центральної частини Чернівців - тривалий особливий історичний процес. Поселення, щц виникло в XIV столітті, зазнало серйозних перетворень міської струткури, щчо відбувалися протягом ХVIII-XX століть. Ці перетворення слугували ваэкливим чинником постійного творення оновленого плану міста, зміни його структурного районування $і$ ця тенденція діс досі. Історичний центр міста протягом тривалого часу змінював свою структуру, розміри, функціональну організацію. Метою дослідження с вивчення та порівняння основних параметрів та характеристик міста на певних історичних етапах иляхом аналізу розвитку його транспортної мережі. Ще однією метою було виявити наявність фортифікаційних об'єктів, які мусіли існувати на ранніх етапах розвитку міста. Методика дослідження базувалася на огляді та аналізі наявних історичних картографічних матеріалів та вивчення розвитку вуличної мережі в історичній частині міста наприкінці XVIII - XX століть. У статті висвітлено фактори, які відіграли важливу роль у формуванні та розвитку центру міста Чернівці, зокрема, зміцнення та розиирення економічних зв'язків. Зәідно з висновками, відкриття нових торгових иляхів стало вирішальним фактором, який вплинув на розвиток Чернівців, визначив структуру міста та напрямки головних вулиць. Інші важливі фактори включають природні умови та місцевий рельєф, соціально-економічний та адміністративний вплив. Дослідження показали, що історичний центр Чернівців розвивася екстенсивно, еволюціонував відповідно до правил та традицій кожсного попереднього періоду. Планувальна структура різночасових районів центру демонструє традиційні форми будовництва характерні для кожного з періодів. Аналіз картографічних матеріалів та історичних джсерел дозволяє охарактеризувати основні принципи розвитку міста. Етапи розростання вуличної мережі та площ, а також тенденції планування жстлових кварталів дають можливість оцінити їх характер, маситаби та розміри. Історичні топографічні карти дозволили нам розробити порівняльні схеми розвитку міст та еволюції межс міста протягом досліджуваного періоду. Центр міста поступово рухався до нових районів у південно-західному напрямку. Ця 
особливість розвитку міста забезпечує ваэжливі матеріали для вивчення міста та його спадкоємного розвитку. Ця робота може бути спрямована в периу чергу на вивчення містобудівної структури, ліній оборони, громадських просторів тощфо Місто розвивалось екстенсивно, розсуваючи межі центру міста, створюючи нові паралельні міські комплекси з новими центральними площами. Найскладнішим завданням для вчених сьогодні є локалізація цих меж для різних emanis.

Наступним складним завданням є з'ясування старих систем оборони, що існували в різних частинах міста в минулому. Повністю невирішеним питанням с те, як оборонні комплекси впливали на розвиток планувальної структури середмістя та передмість. Дослідження дозволило висвітлити передумови великих міських перетворень в історичній частині Чернівців у XVIII - XX століттях.

Ключові слова: вулична мережс, розпланувальна структура, історичний центр, фортифікації, місто Чернівці.

\section{Постановка проблеми.}

Місто Чернівці знаходиться на південному заході України, на перетині важливих загальнодержавних та міжнародних транспортних артерій. Чернівці мають вигідне географічне розташування та транспортне сполучення. Історичний центр міста сформовано на планувальній основі поселення, яке розвивалося, починаючи від XIV ст., але найбільший імпульс у реалізації європейської містобудівної концепції місто зазнає наприкінці XVIII - у XIX ст. Планувальна структура історичного центру міста зазнавала постійних змін. Центр міста переміщувався поетапно на нові ділянки у південно-західному напрямку. Ця особливість розвитку міста, безумовно, дає важливі наочні матеріали для містобудівного вивчення. Це вивчення насамперед може бути скероване на дослідження міської розпланувальної структури, оборонних ліній, громадських просторів та ін. Містобудівні перетворення Чернівців є прикладом європейської толерантності і поваги до історичних та культурних традицій. Дослідники неодноразово підкреслювали, що історія міста - яскравий зразок послідовних змін кількох історичних традицій у міському плануванні, як результат впливу геополітичних реалій кожної з історичних епох на розпланувальну структуру. Місто розвивалося екстенсивним методом, посуваючи межі середмістя та центрального району, творячи нові паралельні містобудівні комплекси 3 новими громадськими центральними площами. Найважчим завданням для науковців сьогодні є локалізація цих меж для різних етапів і вияснення які оборонні системи існували у місті в минулому та як вони впливали на розвиток розпланувальної структури.

\section{Мета роботи.}

На основі аналізу картографічного матеріалу кінця XVIII - XX ст. дослідити взаємозвязок між розвитком вуличної мережі та забудови історичної частини міста, а також спробувати ідентифікувати місця втрачених оборонних об’єктів.

\section{Виклад основного матеріалу дослідження.}

Своєрідні і дуже виразні форми рельєфу визначили розвиток міста і формування його просторової композиції. Долина річки Прут ще з раннього середньовіччя була важливим фактором для утворення поселення. Як колись так і зараз, вона є головною природною віссю, яка відіграла важливу роль у виникненні та розвитку Чернівців. У лівобережній частині заплави у межах сучасного міста, частково збереглося, досліджене археологом Б. 
Тимощуком, Ленківське городище. Воно виникло у XII ст. як один з форпостів ГалицькоВолинської держави, що контролював шлях по долині річки Прут. У 1259 році, коли городище було зруйноване, поселення перемістилося на круті, важкодоступні схили правого берега річки (Тимощук, 1968). Поселення у Ленківцях розміщувалося на пагорбах у заплавній долині ріки, між ії рукавами і складалося з дитинця (замку), посаду та прилеглих підміських утворень (Тимощук, 1968, с.505). Ймовірні залишки дитинця можна ще відчитати на австрійській карті Буковини з 1773-1775 p. (Bukowina, 1773). На карті позначено (на схід від села, яке підписано як «Lenkifze») - квадратний у плані замок, оточений по периметру валом. Всередині двору позначена велика будівля (рис. 1). Біля Ленківців, трохи нижче по течії ріки, позначено понтонну переправу через Прут - “Pontons Brüke” (рис. 1). Ця переправа віддавна, мабуть, була історичним чинником виникнення тут поселень, у тому числі й Чернівців. Крім Ленківців на карті позначено також систему валів давнього городища Цецин. Його позначено на правому березу Пруту, навпроти Ленківців, і підписано «Сzezina». На гребені пагорба позначено чотири поперечні лінії валів, що творять мовби три двори. Це позначення викликає багато запитань і сумнівів чи це оборонний обєкт. Ще один двір, оточений валом по периметру, позначено поряд на південному схилі пагорба (рис. 1). В енциклопедії з історії України подано версію про те, що Цецинський город після знищення Ленківців у XIII ст., перебрав на себе функцію адміністративного волосного центру (Тимощук, 1968, с.505) над районом. Його ж названо попередником Чернівців (Тимощук, 1968, с. 475). 3 позначення залишків валів на карті 1773 р. можна зробити висновок про те, що це колись був великий оборонний комплекс, який складався 3 кількох частин. Його загальна величина однозначно перевищує площу в 1 га території, хоча саме про таку його величину сказано в описі городища-замчища уміщеному в енциклопедії (Тимощук, 1968, с. 475), тому слід було б перевірити які саме об'єкти з карти 1775 р. є тим самим Цецинським городищем.

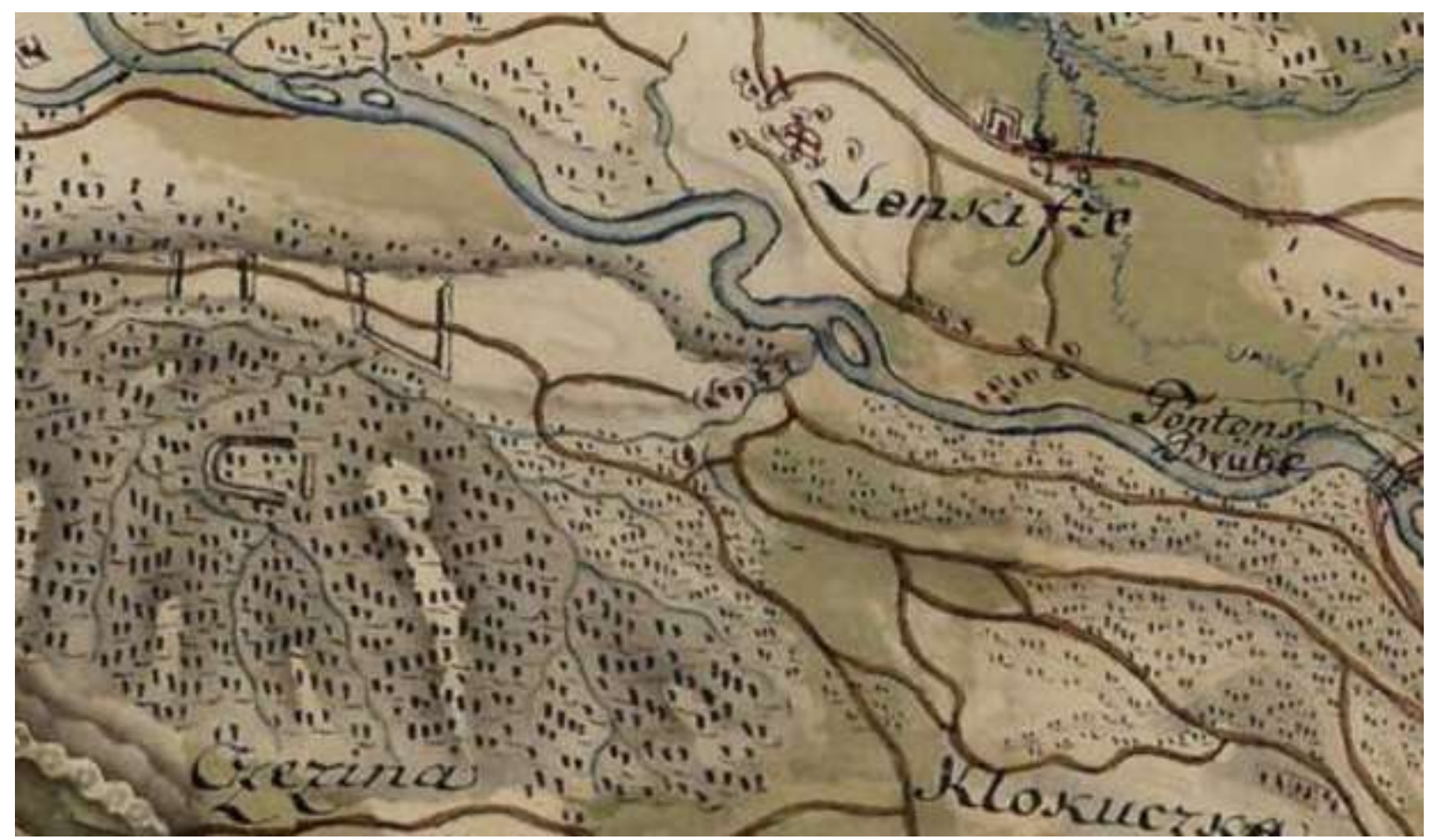

Рис. 1. План валів Цецинського городища за картою 1773-1775 p. Їх позначено “Сzеzіпа”. На лівому березі Пруту квадратом валів позначено оборонний обєкт в Ленківиях - Lenkifze. Важливим є позначення понтонного мосту через ріку - Pontons Bruke (Bukowina, 1773). 
Археологічні дослідження Цецинського об’єкту проводилися кілька разів у XIX та у $\mathrm{XX}$ ст. Матеріали цих досліджень вказують час активного функціонування городища у період X-XV століть. Найцікавішим об' єктом, виявленим на городищі, була кругла мурована вежа-донжон діаметром 20 м, залишки якої знищено наприкінці 1950-х років. В енциклопедичній статті іï названо баштою (Тимощук, 1968, с. 475). Було б дуже добре вивчити матеріалах тодішніх розкопок та зорієнтуватися про місце розміщення вежі по відношенню до периметра стін, а також визначити чи це була вежа чи башта. Якщо вона мала функції донжона, то за архітектурно-типологічною шкалою їі слід було б вважати вежею. На жаль картографічні матеріали 1773-1775 та 1776 рр. не фіксують залишків цього великого (20 м), мурованого, круглого у плані об'єкту (рис. 1 і 2).

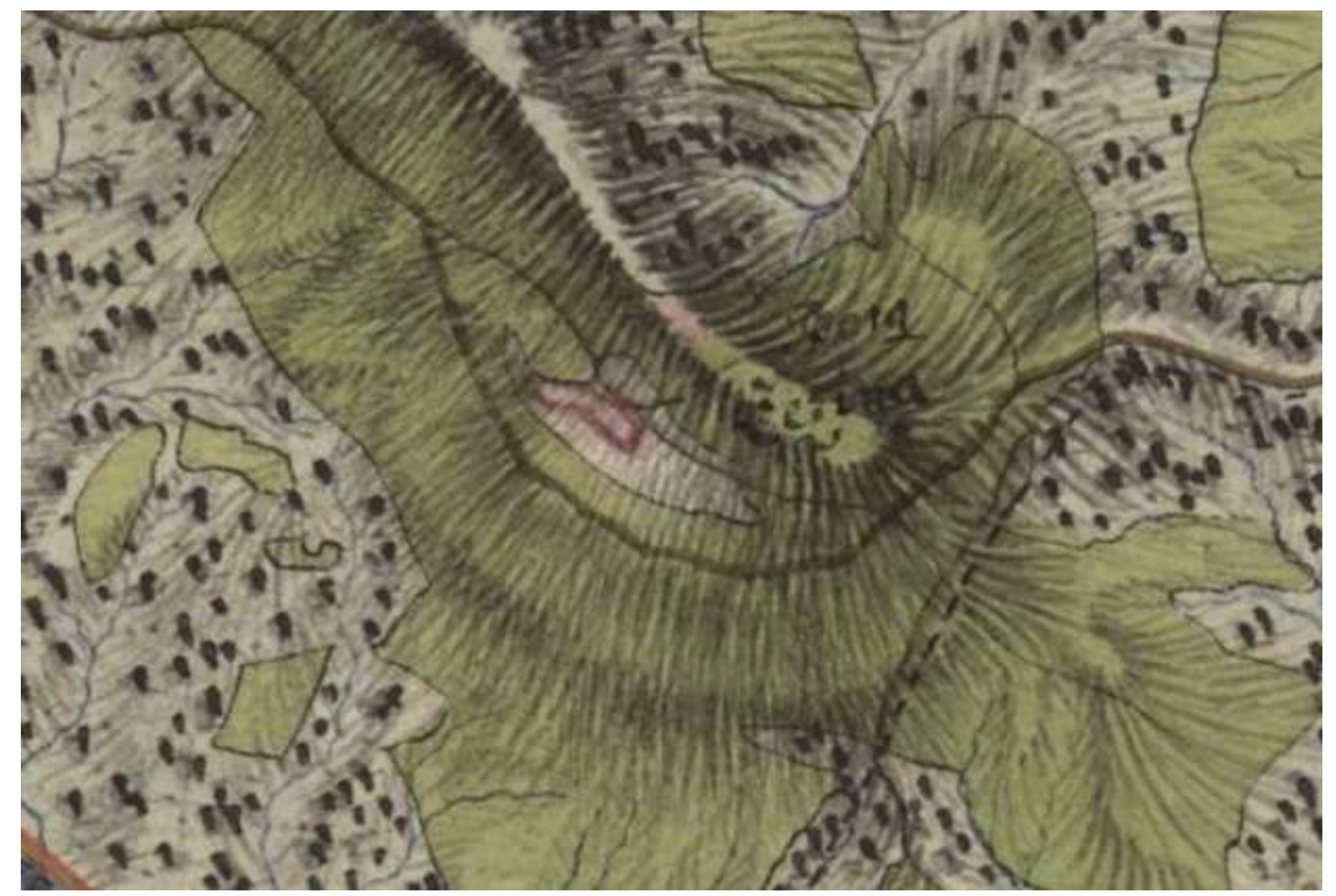

Рис. 2. План Цециинського городища на західній околищі Чернівичів на карті з 1776 р. Об’єкт підписано як -

“Zezina”. (Bukowina, 1776. https://mapire.eu/en/map/firstsurvey-bukovina-2/?layers=140\&bbox=2866711).

В інакшій формі Цецинські релікти фортифікацій виступають на карті 1776 р. (рис. 2). Тут відсутні позначення залишків валів на гребені гори. Натомість руїни об’єкту розташованого на південному схилі гори подано дуже детально. Маємо враження, що позначено периметр оборонних мурованих стін. Про це свідчить застосування червоного кольору для рисування контуру обєкту. В інших місцях цієї ж карти вали позначені чорним коьором. Оборонний об’єкт (замок?) нарисовано у формі великого видовженого двору трохи неправильної конфігурації (прямокутний у східній частині та з ламаними лініями периметру у західній), що оточений повністю з усіх сторін мурованою стіною (рис. 2). Назву об'єкту уміщено поряд із ним і вона позначена як «Zezina». Позначення круглої вежі (башти) відсутні як на першій з 1775 р., так і на другій з 1776 р. картах. Можна припускати, що ця вежа у час складання карти була у стані цілковитої руїни і картографи іï не фіксували. Натомість залишки валів та стін їх цікавили більше, оскільки могли бути використані для створення новітніших укріплень. Історики стверджують про знищення та занепад Цецинського замку у 
XV ст. Залишки Цецинського замчища та круглої вежі-донжону проіснували до 1959 р., коли були знищені під час будівництва телевізійної вежі (Тимощук, 1968, с. 475).

Охарактеризовані вище два оборонні об'єкти, хоча й знаходяться сьогодні у межах сучасної території Чернівців, у минулому були відносно віддалено розміщені від міста. Зародження поселення у місці теперішніх Чернівців, дослідники пов'язують з кінцем XIII XIV ст., коли занепадає Ленковецьке городище. За висновками дослідника архітектурної iсторії Чернівців Б. Колоска міське ядро почало формуватися на північно-східному пагорбі в районі сучасної вулиці Синагоги і поступово розширювалося в межах існуючого нижнього плато, площа якого складала близько 5 га (Колосок Б., 2003). Цьому висновку є археологічне підтвердження слідів поселення XIV-XV ст., що розташовувалося в районі сучасної вулиці П. Сагайдачного. Таким чином природні фактори створили ідеальні умови для захисних та оборонних цілей. Наразі візуально неможливо встановити у просторах центру наявність та характер оборонних укріплень, однак існує припущення про те, що місто було оточено валом з дерев'яним частоколом та ровом. Саме в цей період, ймовірно, Чернівці вперше згадується у грамоті молдовського господаря Олександра Доброго «Уставництво о митах». Документ з датою 08 жовтня 1408 року фіксує Чернівці як митний пункт. Завдяки вигідному географічному положенню, через місто проходив один з важливих торговельних шляхів, який сполучав місто Львів та Сучаву.

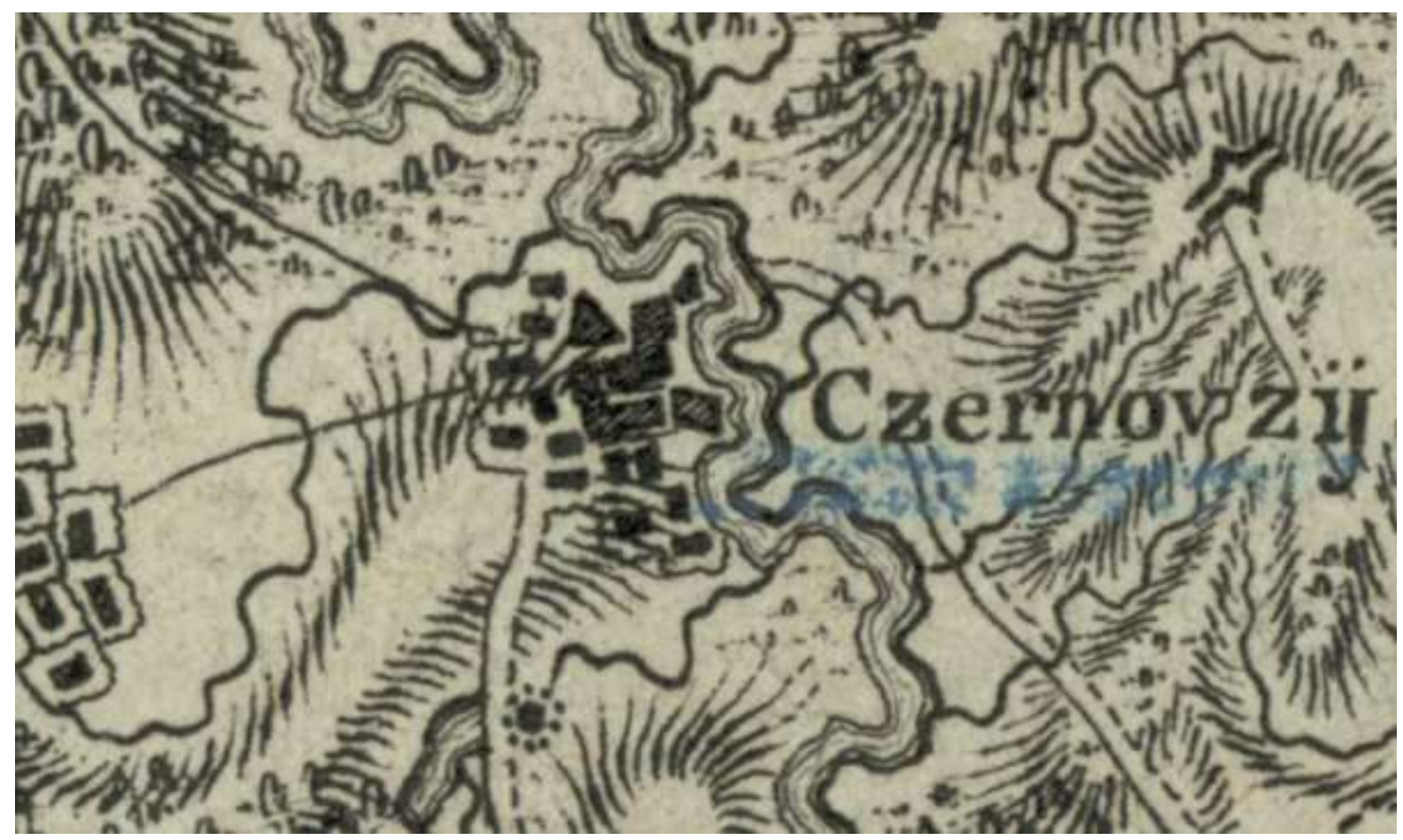

Рис. 3. Карта Фрідріха Бауера з 1769-1771 р. Можна припустити, щзо итрихованими більшими прямокутниками позначено квартали середмістя, а малими позначено передміську забудову. Сдиний оборонний обєкт на карті позначений на лівому березі Пруту на горі у формі форту з двома лініями валів

(Bauer, 1769).

Про просторову структуру середньовічного міста можна ретроспективно гіпотетично міркувати, аналізуючи зображення території Чернівців на картах 1769, 1775 та 1776 років (рис. 3, 4 і 5). Дуже схематична карта 1773-1775 р. першого військового знімання території Буковини (Bukowina, 1773) подає існування двох центральних площ тогочасного міста. Перша (ймовірно старіша площа) знаходилася у районі сьогоднішньої вулиці П. Сагайдачного. Друга позначена у районі нинішньої площі Центральної. Найцікавішим для 
нас елементом карти є позначення у західній частині поселення залишків укріплень у формі валів (рис. 4; нами обведено їх квадратом з пунктирних ліній). Маємо враження, що форма цих валів символізує бастіонний контур якогось укріплення. Позначено лише східне прясло лінії укріплень з залишками чи то двох бастей чи бастіонів (рис. 4).

Набагато детальнішою є карта 11773-1776 р., на якій скрупульозніше представлено розпланувальну структуру міста (рис. 5). На цій карті, як і на попередній, у західній частині поселення позначено існування фортифікаційних об’єктів. Їх тут два. Один розміщений на самому краї мисового підвищення рельфу. Це позначення залишків укріплень з висунутим на схід бастіоном (?), який виступає з ламаної лінії валу з трикутними формами. Бастіон має замкнутий по периметру контур валу, що $є$ нехарактерною рисою для такого типу фортифікації. На рисунку 5 нами позначено це укріплення лівим пунктирним квадратом. Вали першого об'єкту нарисовано двома чорними лініями та зафарбовано у зелений колір (рис. 5). Поряд із ним, трохи на схід, на карті позначено ще один оборонний комплекс укріплений двір квадратної форми з мурованими по периметру будівлями та наріжними баштами чи бастеями. Об'єкт позначено червоним кольором, що свідчить про його мурований характер. Обидва ці об’єкти не підписано ні на карті з 1773-1775 р., ні на карті 3 1773-1776 pp.

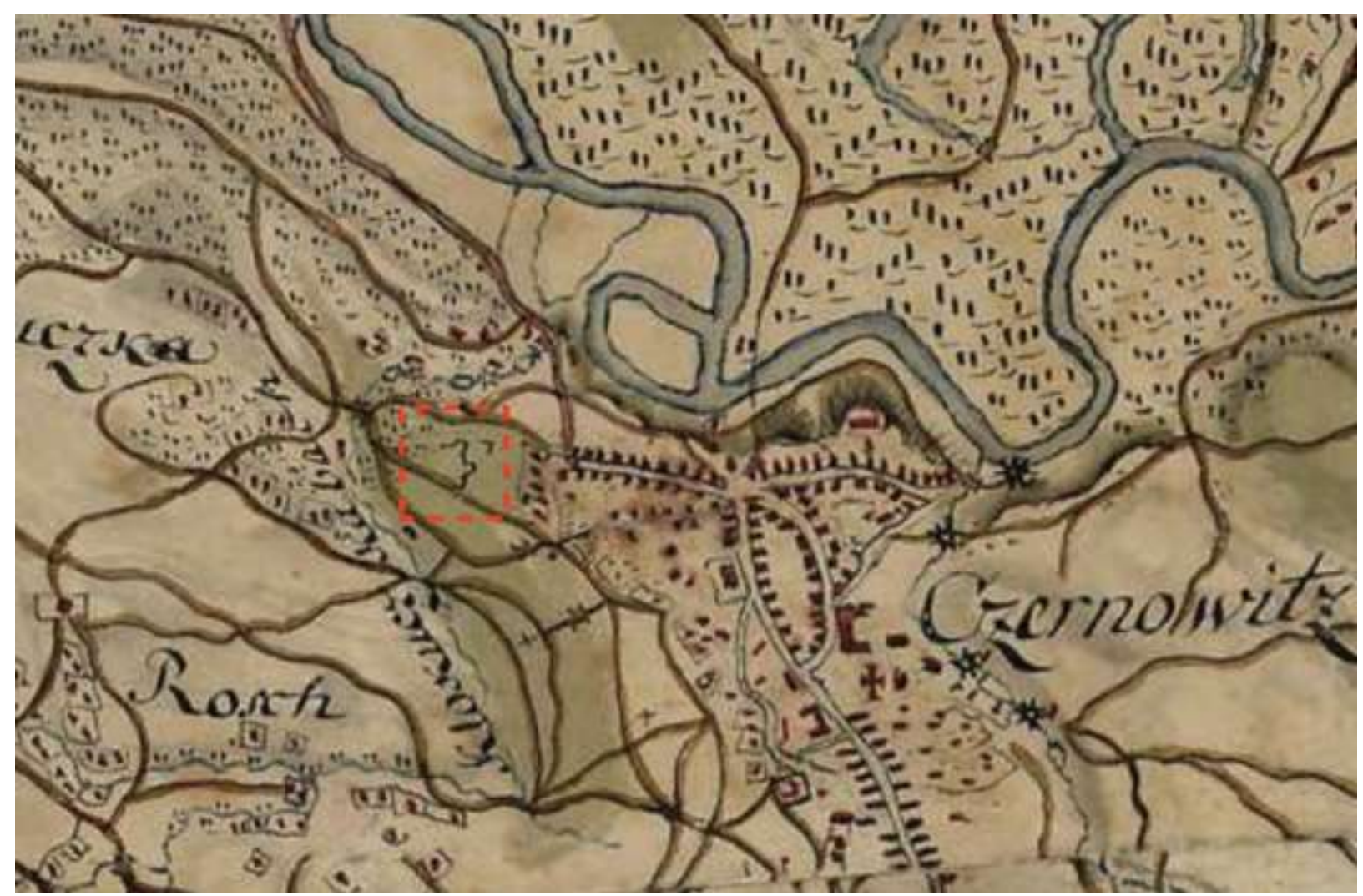

Рис. 4. Залишки бастіонної лінії укріплень у західній частині Чернівців на карті першого військового знімання території Буковини з 1773-1775 pp. (Bukowina, 1773).

Квадратний оборонний двір-замок зустрічаємо також на пізніших картах Чернівців з 1823 та 1830 років (рис. 11 та 12). Саме на карті 1830 р. маємо позначення його функції. Об'єкт підписано як єпископський замок - “Bishöfliches Schloss”. На трохи пізнішій карті 3 1854 р. цей об’єкт вже підписаний не як замок, а як палац (Bischöfliches Palais), що може означати про реалізовану його перебудову та втрату оборонних елементів (https://uma.lvivcenter.org/uk/maps/34431). 


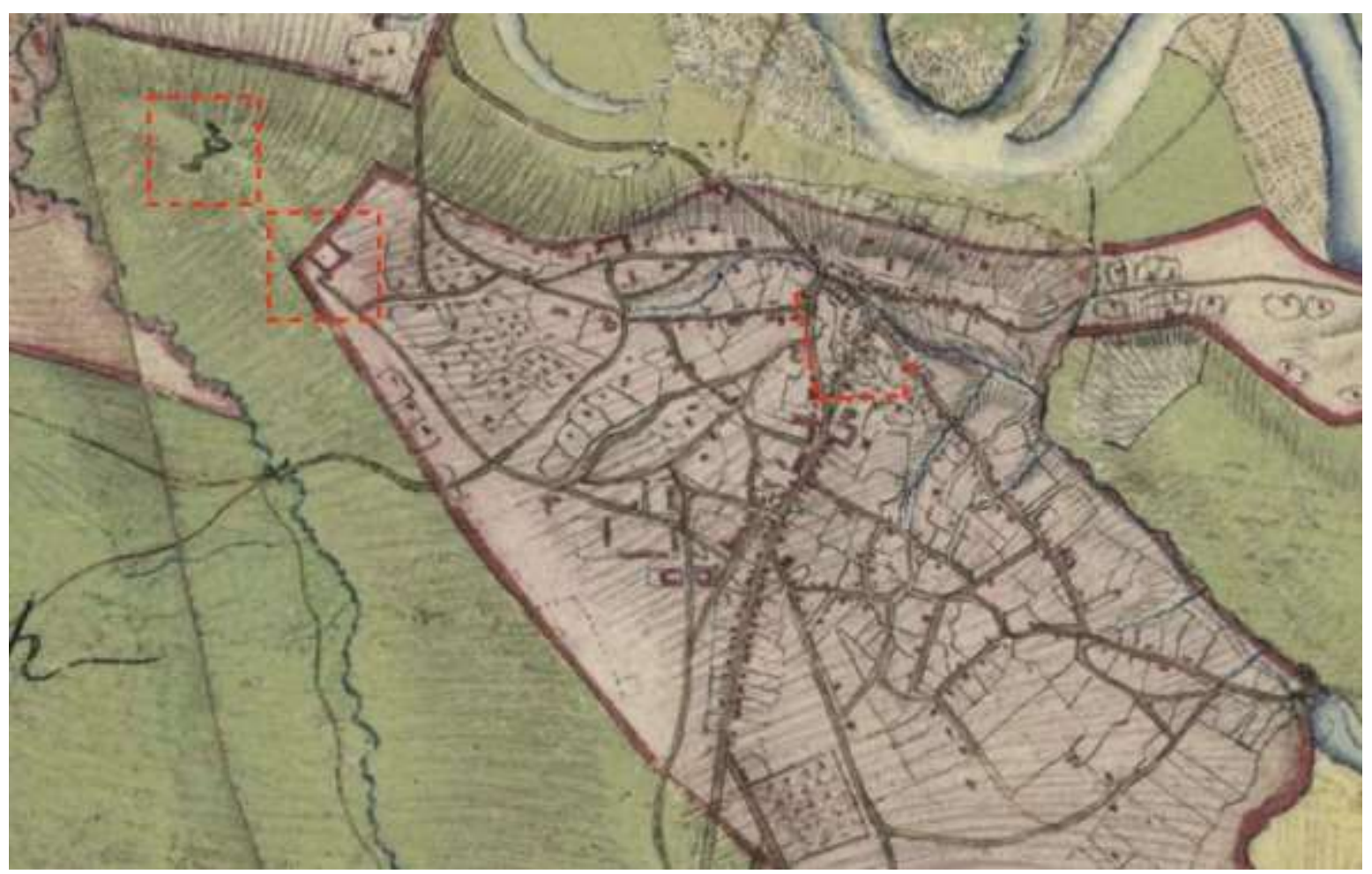

Рис. 5. План Чернівців на карті з 1776 року (Виkowina, 1776). Нами позначено ймовірний пояс укріплень довкола первісного середмістя, а також два оборонні об'єкти у західній частині поселення: залишки бастіонної лінії та квадратної форми єпископський замок з наріжними бамтами чи бастеями.

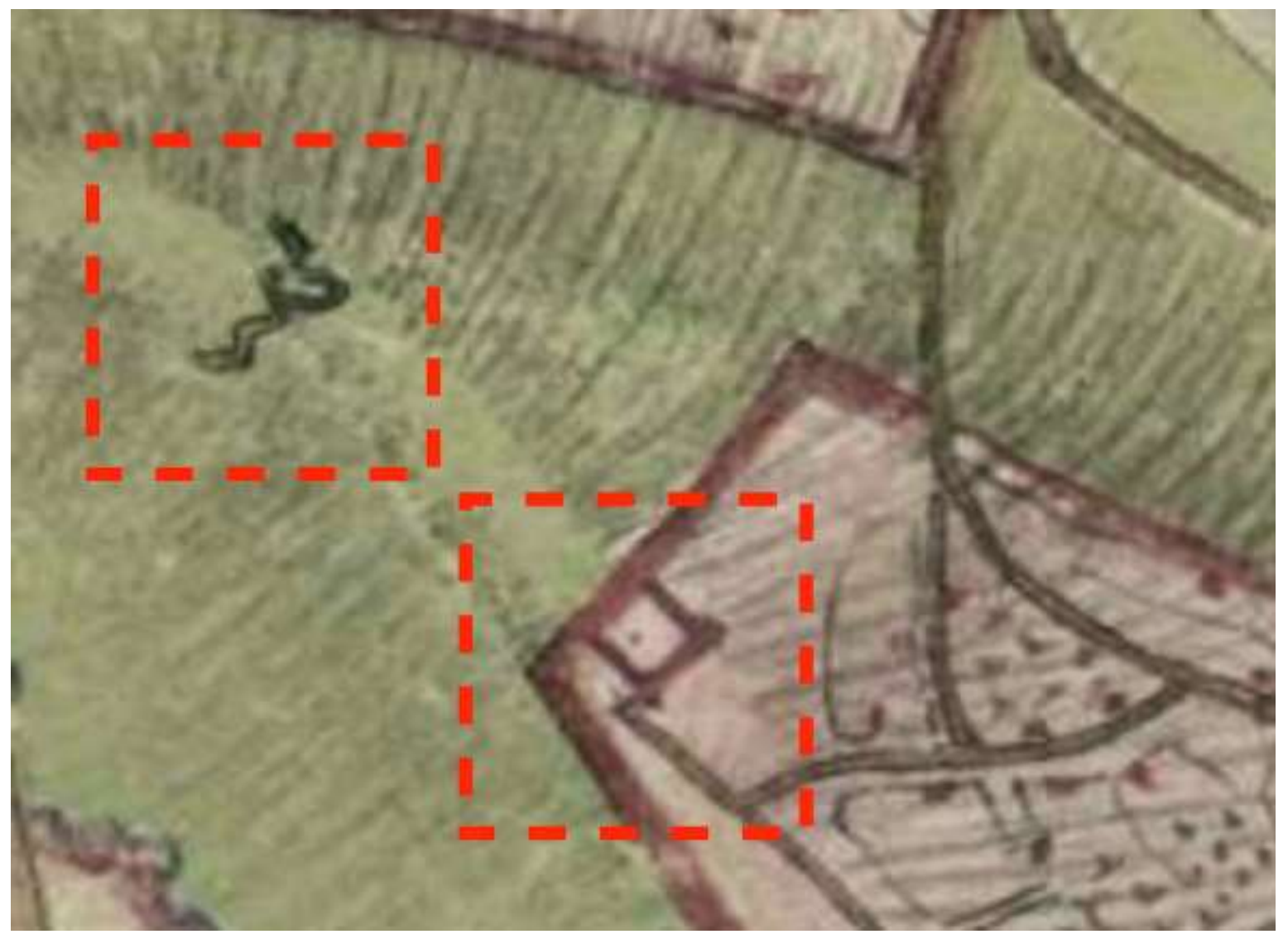

Рис. 6. Фрагмент плану Чернівців на карті з 1776 року (Bukowina, 1776). Позначено залишки валів бастіонної лінії на гребені гори та квадратної форми єпископський замок з чотирма наріжними бамтами чи бастеями. В ’̈зд до замку здійснюється через південну башту. 
Отже нинішній комплекс митрополичої резиденції був зведений архітектором Й. Главкою у 1880 рр. на місці ранішої укріпленої резиденції старости. Це зрештою підверджує його ескіз розпланувальної концепції нової резиденції з 1864 р., на якій ще позначено призначений для зресення старий палац у формі квадратного двору (Nomination, 2008: 2.20).

На карті з 1773-1776 рр. позначено межу території міста. На наш погляд це не реальна межа, а умовна, яка позначає лише межу забудованої території. Якщо перший об'єкт знаходиться поза межами цієї забудованої міської зони, то другий позначено якраз на межі цієї території. Два позначені нами об єкти - це єдині фортифікаційні споруди, які є на історичних картах Чернівців та які пов'язані із середмістям. Їх розміщення у вигідному для оборони місці, на мисовому виступі рельєфу, поза територією середмістя, вказує на те, що це могли бути укріплені замки (двори) представників нобілітету.

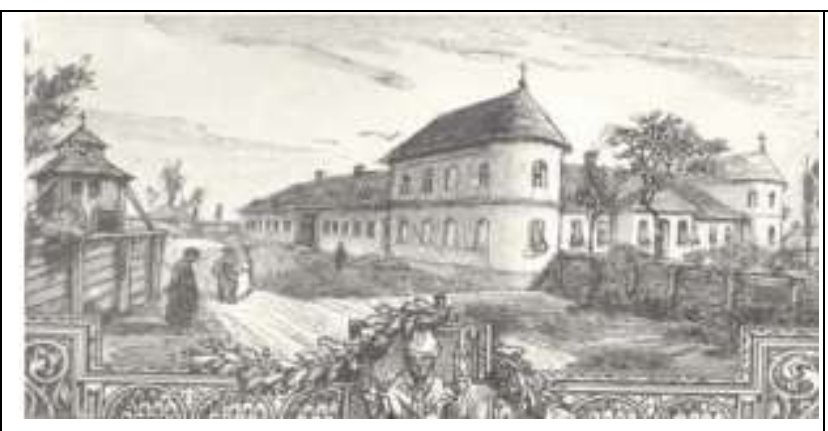

Рис. 7. Рисунок старого єпископського палаиу в Чернівиях, поч. XIX cm. (джерело: Nomination, 2008)

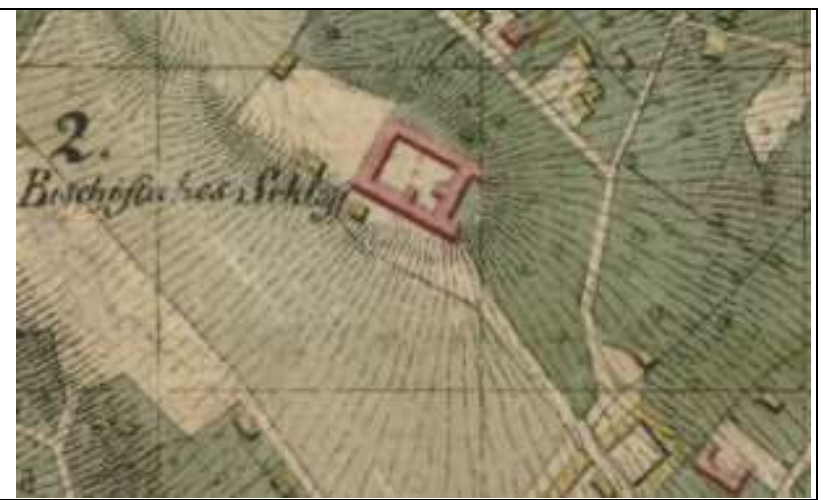

Рис. 8. Спископська резиденція (підписана як «єпископський замок-Bischofliches Schloss» на мапі з 1830 p. (Czernowitz, 1830. mapire.eu).

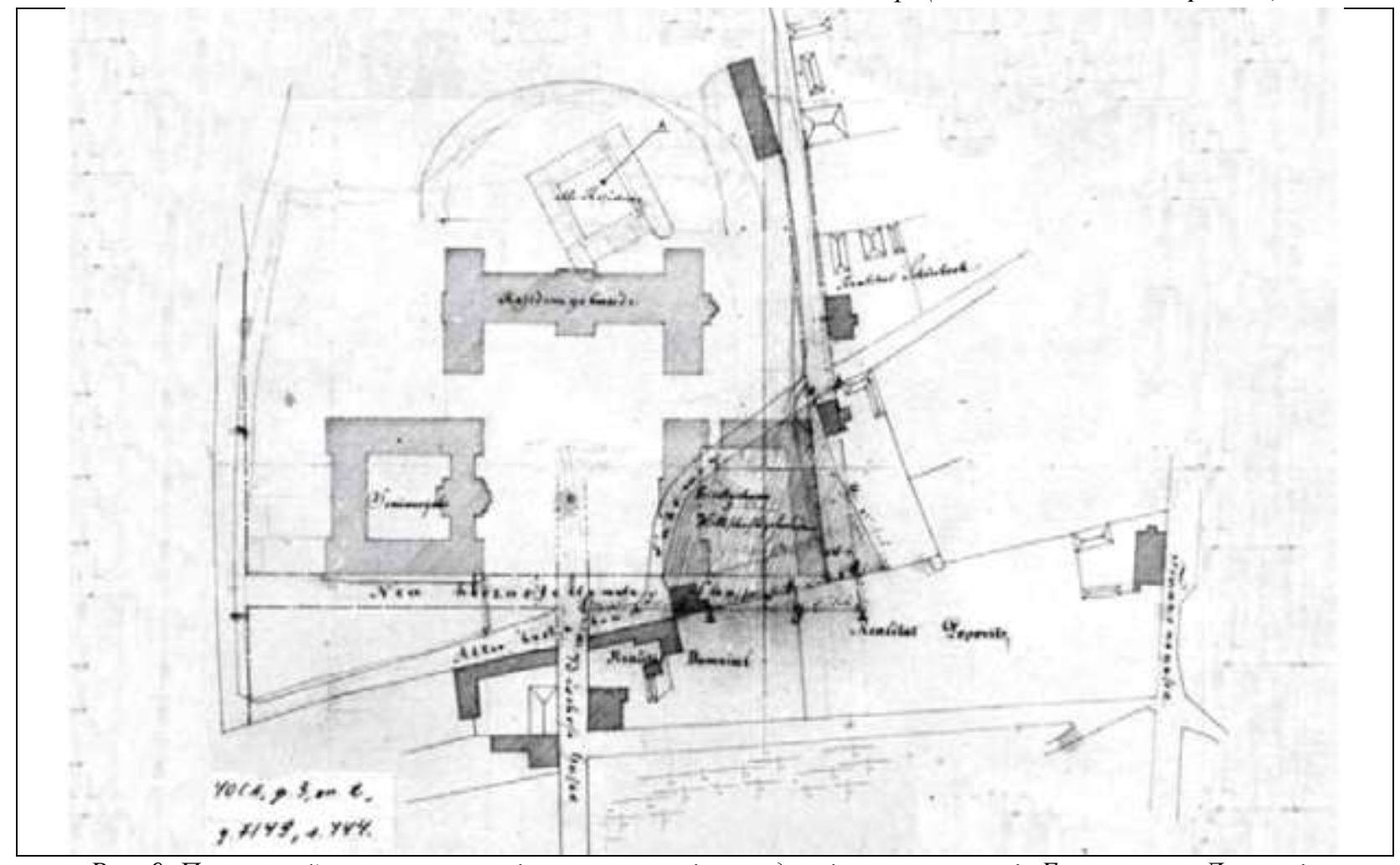

Рис. 9. Проектний кресленик розміщення корпусів резидениії митрополитів Буковини та Далмації, архітектор Й.Главка, 1864 р. На захід від головного корпусу резиденції нарисовано контурною лінією старий палаи (джерело: Nomination, 2008: 2.20). 
У 1488 р. Чернівці отримують привілей на самоврядування на взірець магдебурзького права. Після цієї акції у місті мали би з'явитися ринкова площа та ратуша, а також садибазамок старости. У працях чернівецьких істориків згадується про історичні постаті старост з XVII ст., які були пов'язані з містом. Зокрема, згадуються чернівецький староста Діма, заступник старости Чіходар (Балух, 2014; Балух, 2017). Посада старости у середньовіччі передбачала виконання ролі королівського намісника чи управителя королівських маєтків. Як правило, староста мешкав у замку або укріпленому дворі поза середмістям.

Вище ми вже спробували обгрунтувати нашу гіпотезу про те, що зображені на плані з 1776 р. об'єкти у західній частині міста є пов'язані з існуванням у XV-XVIII ст. садиби старости. Більш західний об'єкт, який виступає у формі руїни, мабуть є старішим двором. Від нього залишився лише вал та руїни бастіону. Новіший східний об'єкт має типову для кінця XVI-XVII ст. форму оборонного замочку з периметральною забудовою квадратного подвір'я 3 наріжними баштами (або бастеми). На карті план цього об'єкту добре прочитається лише частково - у його східній частині. Західне прясло забудови двору накрите грубою фарбованою лінією, яка позначає межу міської забудови. Ця лінія накрила і зробила нечитабельною західне прясло об'єкту. Звертаємо увагу, що видиме східне прясло має специфічні риси оборонного об'єкту: наріжні башти виступають назовні з брили будівлі під кутом; вони мають наближену до квадрата форму; дорога підведена не до куртини стіни, а до південної башти, що також є аргументом щодо оборонної функції об’єкту. В’їздні брами до замків часто влаштовували у баштах.

Відомо, що після приєднання Буковини до Австрійської держави, у 1775 р. було утворено Буковинську єпархію з центром у Чернівцях. Для осідку єпархії було передано колишню садибу старости Чернівців (Енциклопедія, 2013). Отже аналізований нами обєкт 3 карти 1776 р. є тим самою садибою старости, яка після передання іiї для владик та консисторії була перебудована. Вважаємо, що перебудова оборонного об’єкту відбулася після 1776 р. На пізніших планах міста можна побачити змінений план двору - наріжні башти розібрано та перебудовано у формі святинь з півкруглими апсидами. До східного корпусу, посередині добудовано вхідний ризаліт. Вигляд цього старого єпископського двору подано на рисунку з початку XIX ст. (рис. 7). Перебудований характер плану об'єкту зафіксовано також на карті Чернівців 31830 р. (на рис. 8 подаємо ії побільшений фрагмент). Тобто інформація в інтернет-ресурсах про «зведення у короткий термін Єпископської резиденції» (Чернівці, 2020) не є правильною. Резиденцію було створено шляхом перебудови старого старостинського двору, а не новим будівництвом. Вже ця перебудована резиденція $\epsilon$ зафіксована на ескізі новітнішої резиденції, що його виконав архітектор Й.Главка, шукаючи композиційно-планувальну структуру нового комплексу у 1864 р. (рис. 9).

Детальніша ідентифікація та інтерпретація оборонних об’єктів з карт 1773 та 1776 р., вивчення їх зв'язку з історією Чернівців - вважаємо за актуальне наступне завдання для археологів та дослідників історії міста.

За дослідженнями спеціалістів інституту «Укрзахідпроектреставрація» (Могитич, 2003), структура давніх Чернівців мала декілька містоутворюючих осей, напрямки яких співпадали з основними торговельним шляхами. Зокрема у межах Чернівців по сучасних вулицях Ю. Гагаріна, Капеланській, М.Чернишевського здійснювався рух у напрямку Снятина та Львова. Дорога на захід по вулицях П. Сагайдачного та Руській вели до поселень над Прутом і далі - до Ясс. Друга містоутворююча вісь пролягала на південь сучасними вулицями Головна та Героїв Майдану і вела до Сирету і Сучави. Ще одна 
містоутворююча вісь співпадає з вулицями Б. Хмельницького та Синагоги, де проходила місцева дорога та з’єднувала прилеглі села Калічанка і Роша (Могитич, 2003).

Перший інвентаризаційний план міських земельних наділів розроблений інженером Пітцеллі у 1787 році (рис. 10). На цьому плані нанесено 417 земельних ділянок, кожна з яких має власний номер. Розміри ділянок різні за величиною. Невеликі земельні ділянки-парцелі знаходились в районі вулиць Синагоги, Головної, Ш. Алейхема, П. Сагайдачного, а також на відрізку вулиці Головної від Центральної площі до Соборної. Ймовірно зона поширення цих малих парцелей вказує на межі території колишнього середмістя. Зважаючи на цей фактор нами позначено на карті 1776 р. умовну гіпотетичну лінію фортифікацій довкола середмістя станом на XV-XVI ст. (рис. 4).

Саме ці території характеризуються найвищою щільністю забудови. Структура вулиць, що утворюють житлові квартали має нерегулярний характер, однак напрямки деяких 3 них були використані у подальшій розбудові міста і збереглися до цього часу. Характер розподілу цих малих парцелей свідчить, на нашу думку, що місто мало два етапи розвитку до XVIII ст. Перше старе середмістя знаходилося у районі вулиці П. Сагайдачного. Воно мусіло мати укріплення у формі валів та бойового паркану (валу з дерев'яною стіною 3 бійницями). Такі укріплення типові та широко розповсюджені у XV ст. Межі цього середмістя та ймовірна лінія його укріплень легко відчитується на карті за величиною малих парцель приблизно одинакової величини.

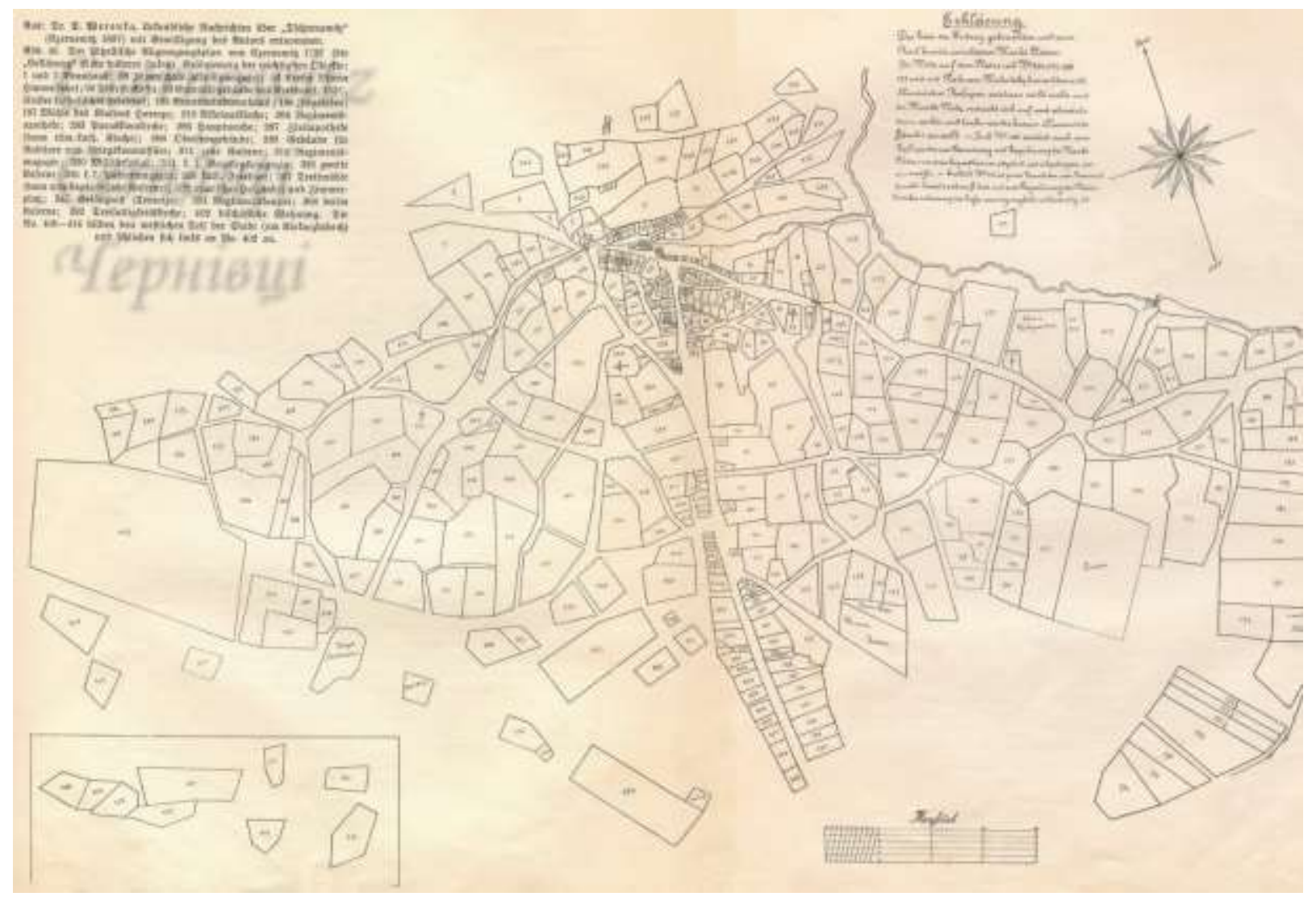

Рис. 10. План Пітиеллі 1778 року.

Після включення Буковини та Чернівців до складу Австрійської монархії цісарська влада почала упорядкування шляхів, зокрема дороги, яка вела з Моравії через Львів, Галич, Чернівці до Сучави і Семигороддя. Завдяки цьому пожвавилися економічні зв'язки та торгівля, що стало поштовхом для розвитку міста і прилеглих територій. Відповідно до 
статуту міста від 1786, яку описує Р.Ф. Кайндль, передбачалося зміни дерев'яної забудови на кам'яну а також планування вулиць і площ. Одразу розпочалося впорядкування міських вулиць, зокрема вулиці Головної від вулиці Гагаріна до Центральної площі, а згодом - i нинішньої вулиці П. Сагайдачного в районі нижнього міста.

Згодом місто розвивається у південному напрямку та утворюється нове місто, з новим центром у районі нинішньої площі Центральної (колишня плоша Ринок). Не маємо сумніву, що ця нова частина міста також мала свої власні укріплення, які мали б бути зведені у новітніших формах. Типові лінії міських укріплень для періоду XVI-XVII ст. - це характерні пояси бастейного чи бастіонного характеру, які будувалися найчастіше у землянодерев'яних конструкціях.

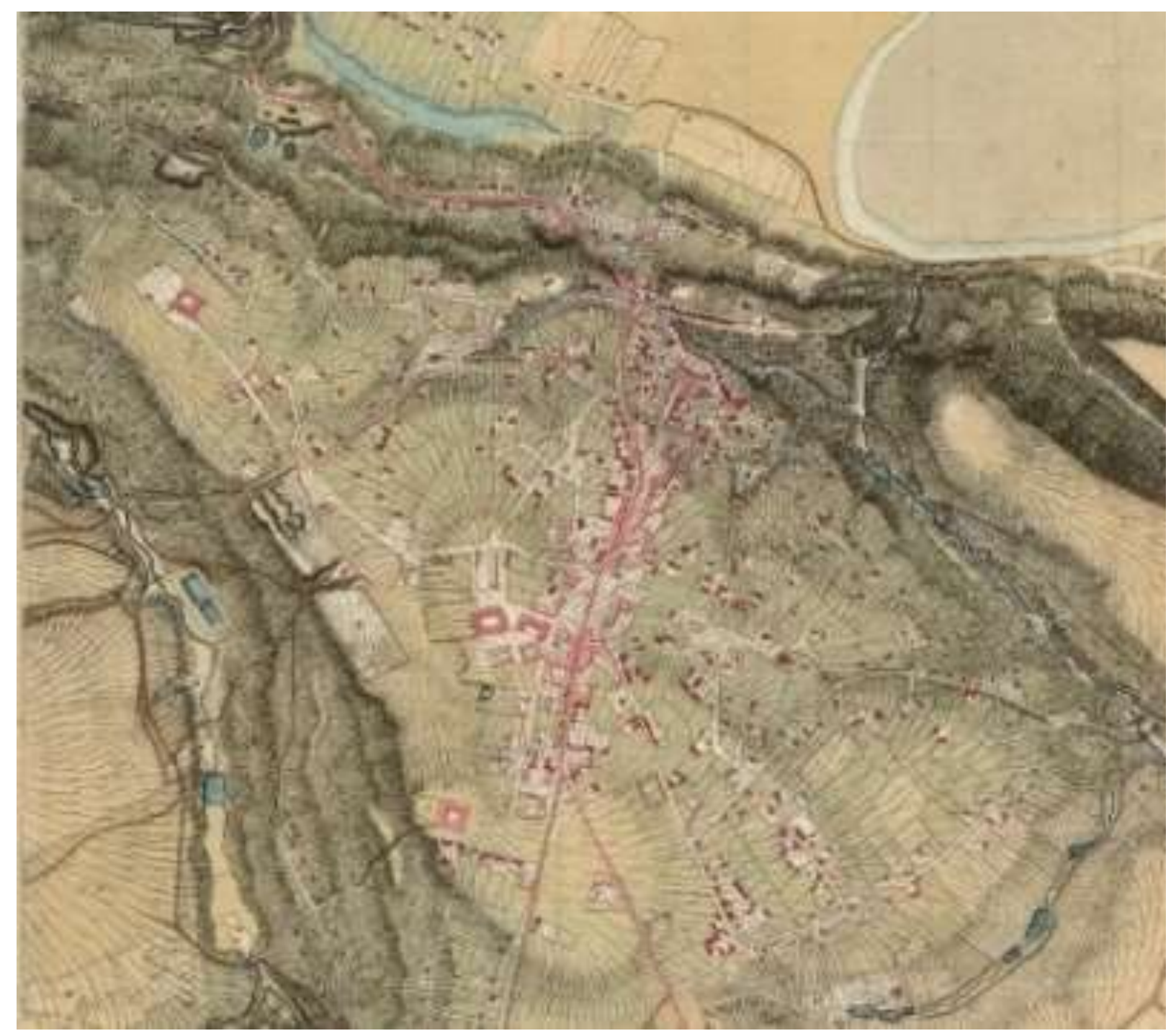

Puc. 11. Mana 1823 року.( Czernowitz, 1823. https://uma.lvivcenter.org/en/maps/34429)

Починаючи з 1793 року міським урядом було запроваджено правила нового будівництва, яке мало відбуватися відповідно до затвердженого плану та 3 дотриманням основних параметрів вулиць. Початок Австрійської доби, аж до середини XIX сторіччя, має надзвичайно важливе значення 3 точки зору започаткування та реалізації оновленої планувально-просторової організації міської території. Ці тенденції характерно видимі на мапі 1823 року (рис. 11) Місто, як і раніше розвивається в південному та південно-східному напрямку. Не змінилися основні торговельні шляхи та дороги до поряд розташованих сіл. 
Однак в планувальній структурі міста відбулися суттєві зміни. Новий масштаб і характер вулиць та площ докорінно змінює незручне, існуюче на той час, розпланування територій. Тим самим нова влада прагнула підкреслити статус Чернівців, як важливого адміністративного центру. В цей час починають формуватися Центральна площа (1825р.), та сучасні вулиці Руська, О. Кобилянської, Т. Шевченка, Університетська, Українська, Шептицького, проглядаються контури площі Філармонії. Формування нового центру має важливе значення, оскільки саме параметри площі, характер та архітектура будівель створює своєрідний масштаб та неповторний образ, який поступово поширюється на прилеглі території міста. Запроваджені владою пільги, створюють ідеальні умови для нового будівництва. В результаті починають з'являтися перші кам'яні будівлі, а також сакральні будівлі (позначені на мапі). Деякі з них збереглися понині.

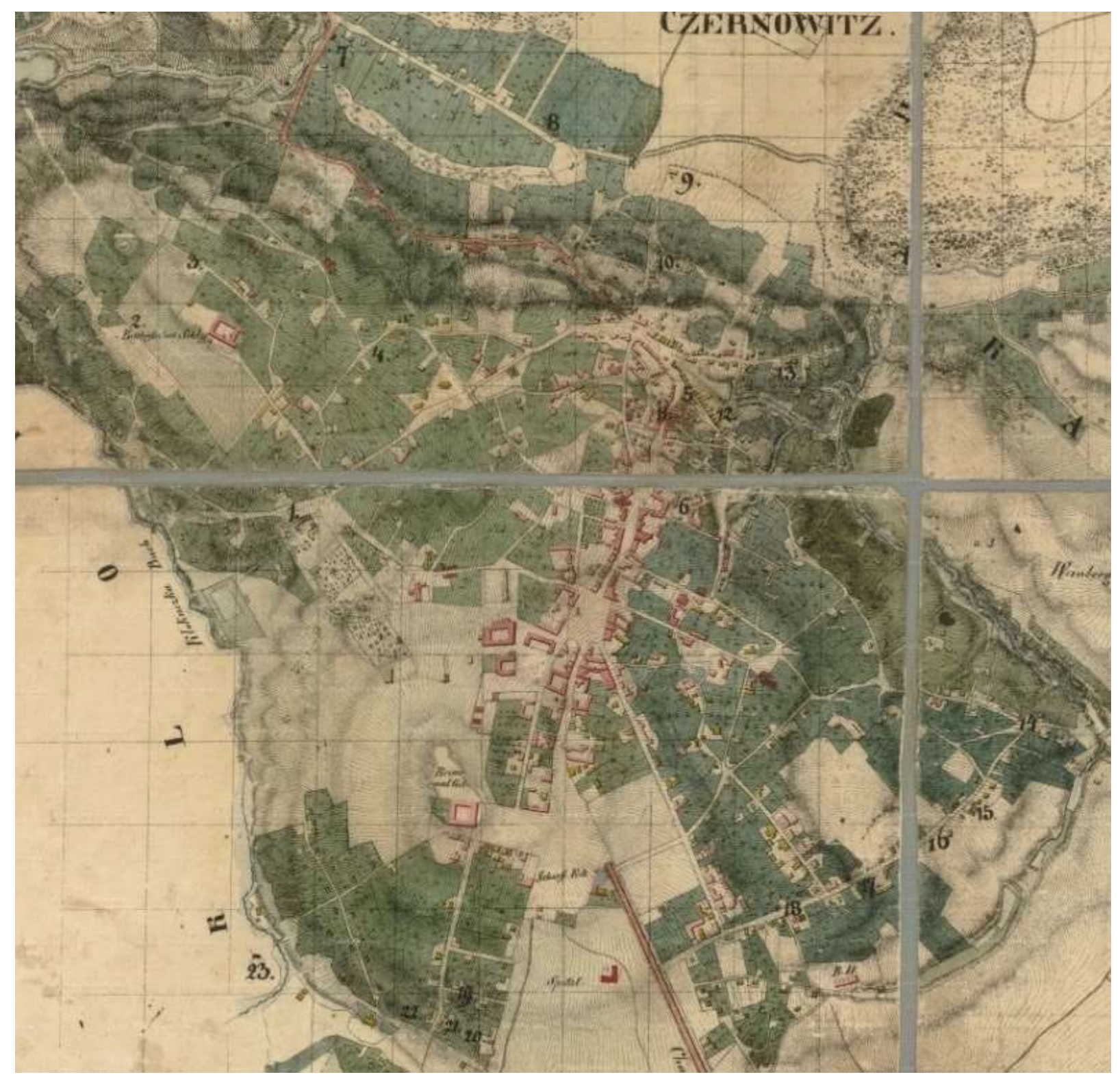

Puc. 12. Maпа 1830 року. (Czernowitz, 1830).

Міська територія має еліпсовидну форму. Це стало можливим завдяки природній межі крутих схилів, які оточували місто. Більш сприятливі території з півдня та заходу 
обгрунтовують розширення міста саме у цьому напрямку. Площа міста, на той час, складала приблизно $160-180$ га.

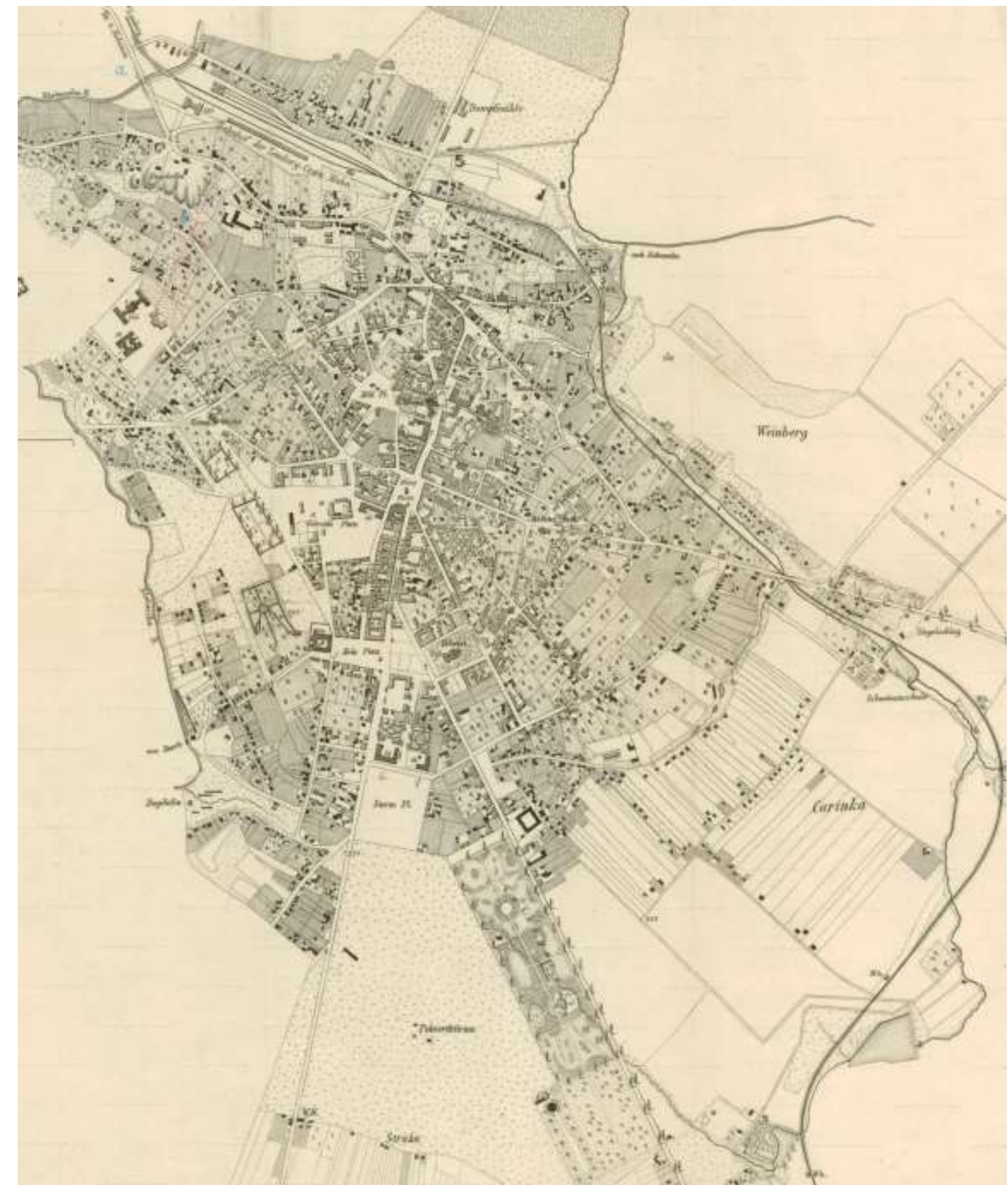

Puc. 13. Mana 1880 року (Czernowitz, 1880).

Аналізуючи природні фактори, ландшафт можна прийти до висновку, що саме вони відіграли важливу роль у формуванні міських доріг, характеру та напрямків їх прокладання. У результаті чого місто має унікальний планувальний каркас. На одному 3 прикладів хотілося зупинитися більш детально.

Характерним i впізнаваним є природне утворення - тальвег, де протікала річка i утворювала каскад водойм. У зв'язку з розширенням міста починають освоюватися територій у поймі цієї річки (мапа 1874-1880 року; рис. 13) і поступово утворюється сучасна вулиця Л. Кобилиці. Як довела практика такі прийоми будівництва не виправдовують себе. Під час раптових дощів вулиця перетворюється у повноводну річку. Аналіз інших вулиць, 
там де протікали річки, зокрема вулиця Б. Хмельницького є додатковим підтвердженням цього недоліку у містобудуванні.

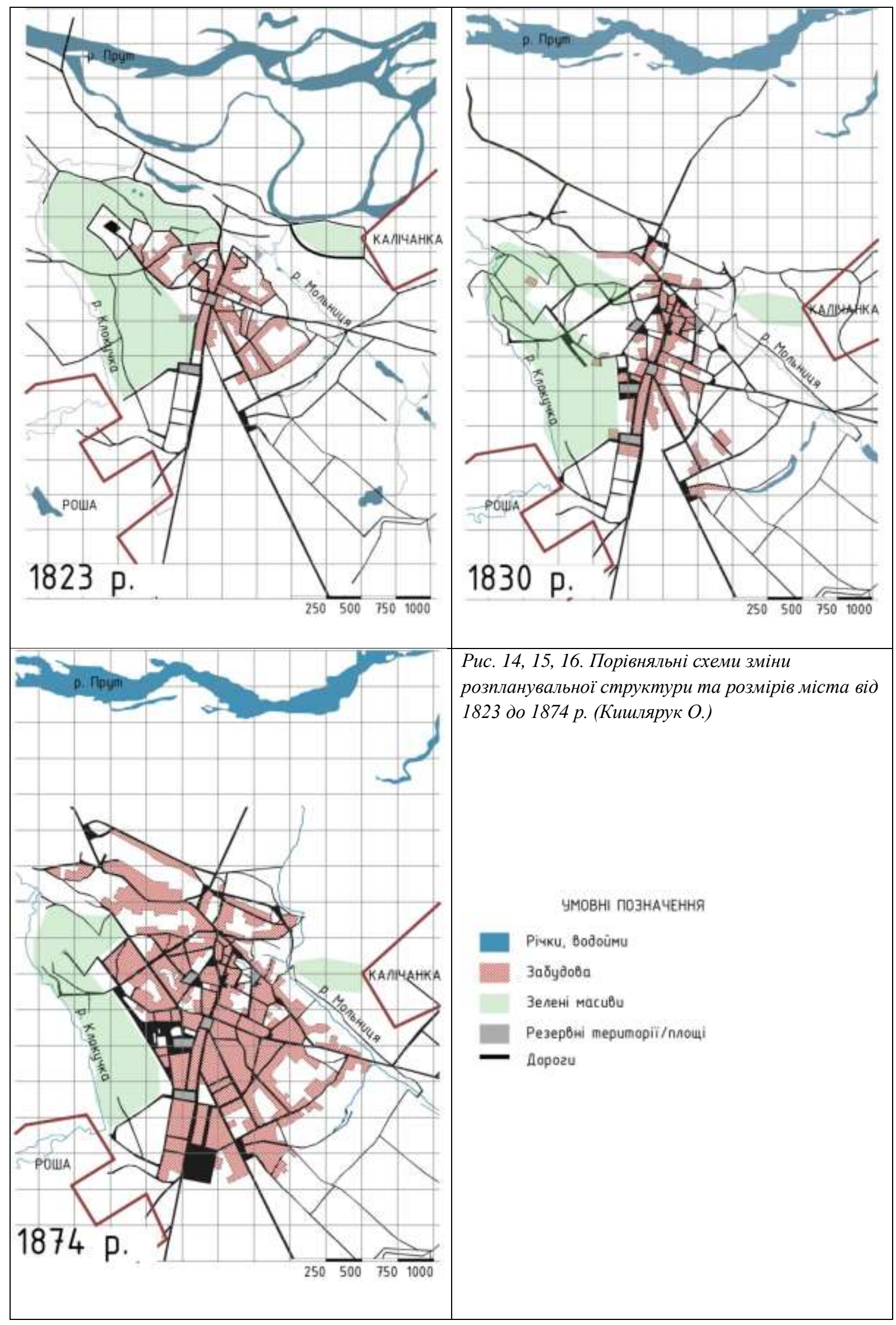


Складний рельєф, та природні обмеження ще тривалий час будуть стримувати розвиток міста в північному напрямку. Тільки 3 появою залізничного сполучення між Львовом $\mathrm{i}$ Чернівцями, будівництво якого завершилося у 1866 році почалося освоєння територій в заплаві річки Прут. 3 північної сторони, в районі, нинішньої вулиці Ю. Гагаріна було споруджено будівлю залізничного вокзалу.

На початку XX ст. побудовано новий вокзал, який функціонує і зараз. Залізнична колія пролягає у напрямку Сучави у долині річки Мольниця, а у напрямку Львова уздовж вулиці Ю. Гагаріна і перетинає річку Прут.

На карті 1880 року сформувалися нові межі міста, які на сході межували з передмістям Калічанкою (вулиця Січових стрільців) і вздовж річки Мольниця проходили до сучасної вулиці Залозецького. На півдні було закладено міський сад - сьогодні парк Т. Шевченка. Межі земельної ділянки співпадають з нинішньою межею парку. 3 заходу межа пролягала вздовж річки Клокучки. У цих межах здійснювалося розпланування вулиць і доріг, в результаті чого поступово формувалося невеличке, компактне місто. Для історичної частини Чернівців характерним є наявність головної вулиці, яка пронизує все місто, та радіальної структури решти вулиць. Від площі Ринок (Центральна) відходять вулиці Руська, Головна у північному та південному напрямку, І. Франка, О. Кобилянської, Поштова, Університетська. Найдовшими на той час були вулиці П. Сагайдачного, Руська, Б. Хмельницького, 28 Червня, О. Кобилянської, Головна.

У центральній частині міста розвивається густа сітка вулиць 3 більш щільною забудовою, що є свідченням тяжіння міщан до традиційного центру. Слід звернути увагу на те, вулиці та площі планувалися з врахуванням композиційних та об'ємно-просторових вимог, де великого значення надавалося будівлям з елементами домінант.

Найбільш значимими будівлями того часу були будівлі сакрального призначення i, безумовно, новобудови міської Ратуші і Резиденції Буковинських митрополитів. 3 часом вони стали символом та візитівкою Чернівців. До середини XIX ст. були визначені межі міста та перспективи нового будівництва. Продовжується освоєння міських територій вільних від забудови у всі напрямки від центру. Там з'являються нові вулиці, площі, парки, сквери, приватні та громадські будинки. Період середини XIX- початку XX ст. є важливим i визначальним у містобудівному значенні для Чернівців.

На початку XX ст. формування історичного центру знаходилося у своїй завершальній фазі. Невелике за розмірами місто, в основі якого закладені планувальні принципи європейського типу впродовж тривалого часу змінювало свою структуру, розміри, функціональну організацію, знаходячи неповторний характер, який і зараз визначає його обличчя. Добре оздоблені вулиці та площі висока щільність забудови, розвинута вулична мережа, упорядковані парки та сквери надали місту особливий імідж, про який і досі ходять легенди.

\section{Висновки.}

Як попередній висновок можна зробити припущення, що у Чернівцях на всіх етапах розвитку міста не було реалізовано будівництва потужних фортифікацій, як це мало місце у Снятині, Сучаві, Хотині, Жовкві чи Бродах. Проте місто мало укріплене валами середмістя та замок подібно до інших міст, що розвивалися у XV-XIX ст. Залишки старших та новіших укріплень старостинського замку демонструють плани міста на картах $з$ кінця XVIII ст. Їх виявлення в натурі та ідентифікацію слід пов'язувати з археологічними дослідженнями, які варто було б запланувати. 
Дослідження картографічного матеріалу дало можливість проаналізувати розвиток вулиць та доріг а також передумови містобудівних перетворень історичної частини міста. Розвиток просторово-планувальної структури залежав від багатьох факторів, зокрема: від формування міста на території з більш раннім поселенням, складного рельєфу, природних гідрографічних умов, а також від цілевих архітектурно-планувальних заходів, які коригувалися владою у звязку 3 наявними соціально-економічними чинниками та реалізувалися адміністративно-правовим регулюванням.

\section{Використана література та джерела:}

Балух, 2017. Балух О. Буковина під час стабілізації воєнно-політичної ситуації у молдавській державі (1621 - 1650 pp.). 2017 [online] Avialiable at: https://zenodo.org/record/400754\#.YB5vu3czbUI [Accessed 2 October 2020]

Балух, 2014. Балух О. В. Буковина у складі молдавської держави у 1563-1600 рр.: воєннополітичний аспект [в] Сумська старовина. №XLIII-XLIV. 2014. с. 14-27 [online] Avialiable at: https://shron1.chtyvo.org.ua/Balukh_Oleksii/Bukovyna_u_skladi_Moldavskoi_derzhavy_u_1539-

1563_rr.pdf [Accessed 2 October 2020]

Ботушанський, 2009. Ботушанський, М. В., ред., 2009. Чернівці: Історія і сучасність (Ювілейне видання до 600 - річчя першої писемної згадки про місто). Чернівці: Зелена Буковина.

Вечерський, 2008. Вечерський, В. В., ред., 2008. Історико - містобудівні дослідження Чернівців. Київ: 2008.

Енциклопедія, 2013. Чернівці [в] Енциклопедія історії України, Київ, Наукова думка, 2013, т. 10, c. 505 [online] Avialiable at: http://history.org.ua/LiberUA/978-966-00-1359-9/978-966-00-1359-9.pdf [Accessed 10 October 2020].

Кайндль, 2005. Кайндль, Р. Ф. Історія Чернівців від найдавніших часів до сьогодення. Переклад 3 німецької В. Ю. Іванюк. Чернівці: Зелена Буковина, 2005.

Колосок, 2003. Колосок, Б. Містобудівна спадщина Чернівців. Архітектурна спадщина Чернівців австрійської доби. (матеріали конференції 1 - 4 жовтня 2001 р). Чернівці: Золоті литаври, 2003.

Могитич , 2003. Могитич, Р. Містобудівний розвиток Чернівців у XIV-XIX ст. Шляхи охорони урбаністичного середовища міста. Архітектурна спадщина Чернівців австрійської доби. (матеріали конференції 1 - 4 жовтня2001 р). Чернівці: Золоті литаври, 2003.

Тимощук, 1968. Тимощук Б. Дорогами предків. Ужгород, 1968.

Чернівці. 2019. [online] Avialiable at: https://uk.wikipedia.org/wiki/\%D0\%A7\% D0\%B5\%D1\%80\%D0\%BD\%D1\%96\%D0\%B2\%D1\%86\%D1\%96 [Accessed 1 October 2020]

Bauer, 1769. Bauer F. Carte de la Moldavie pour server á l'histoire militarede la querre entre les Russes et les Turcs. Amsterdam, inter 1769-1771. [online] Avialiable at: https://polona.pl/item/carte-de-lamoldavie-pour-servir-a-l-histoire-militaire-de-la-guerre-entre-les-russes-et,NDU2MjU1OTk/ [Accessed 1 October 2020]

Bukowina, 1773. Distrikt Bukowina (1773-1776) - First Military Survey [online] Avialiable at: <https://mapire.eu/en/map/firstsurvey-bukovina-2/?layers=140\&bbox $=2866627>$ [Accessed 1 October 2020]

Bukowina, 1776. Distrikt Bukowina (1773-1776) - First Military Survey. Austrian War Archive, Vienna. [B IX a 432] [online] Avialiable at: https://mapire.eu/en/map/firstsurvey-bukovina2/?bbox $=2866711.4052038062 \% 2 \mathrm{C} 6090672.0765940165 \% 2 \mathrm{C} 2890710.6904279124 \% 2 \mathrm{C} 6098333.460544$ 25 [Accessed 1 October 2020]

Czernowitz, 1823. Map of the city of Czernovitz, 1823. Austrian War Archive, Vienna. GIh 131 [online] Avialiable at: https://uma.lvivcenter.org/en/maps/34429) [Accessed 1 October 2020]

Czernowitz, 1830. City of Czernowitz. 1830. Austrian War Archive, Vienna. GIh 131-6 [online] Avialiable at: https://uma.lvivcenter.org/en/maps/34430 [Accessed 1 October 2020]

Czernowitz, 1880. Map of Czernowitz. Expanded in 1880 (Plan von Czernowitz. Ergänzt im Jahre 1880) Austrian War Archive, Vienna. GIh 133. [online] Avialiable at: https://uma.lvivcenter.org/en/maps/34432 [Accessed 1 October 2020] 
Galicia and Bucovina, 1861. Galicia and Bucovina (1861-1864) - Second military survey of the Habsburg Empire [online] Avialiable at: <https://mapire.eu/en/map/secondsurveygalicia/?layers $=11 \&$ bbox $=2650396.6280172416 \% 2 \mathrm{C} 6410880.850074071 \% 2 \mathrm{C} 2698743.0484076156 \% 2 \mathrm{C} 6$ 426168.255731106> [Accessed 1 October 2020]

\section{References:}

Balukh, 2017. Balukh O. Bukovyna pid chas stabilizatsiyi voyenno-politychnoyi sytuatsiyi u moldavs'kiy derzhavi (1621 - 1650 rr.). 2017 [online] Avialiable at: https://zenodo.org/record/400754\#.YB5vu3czbUI [Accessed 2 October 2020]

Balukh, 2014. Balukh O. V. Bukovyna u skladi moldavs'koyi derzhavy u 1563-1600 rr.: voyennopolitychnyy aspekt [v] Sums'ka starovyna. №XLIII-XLIV. 2014. s. 14-27 [online] Avialiable at: https://shron1.chtyvo.org.ua/Balukh_Oleksii/Bukovyna_u_skladi_Moldavskoi_derzhavy_u_15391563_rr.pdf [Accessed 2 October 2020]

Botushans'kyy, 2009. Botushans'kyy, M. V., ed., Chernivtsi: History and modernity (Jubilee edition to the 600th anniversary of the first written mention of the city). Chernivtsi: Zelena Bukovyna, 2009.

Bukowina, 1773. Bukowina (1773-1775) - First Military Survey. [online] Avialiable at: <https://mapire.eu/en/map/firstsurvey-bukovina/?layers=139\&bbox > [Accessed 1 October 2020]

Bukowina, 1776. Distrikt Bukowina (1773-1776) - First Military Survey. Austrian War Archive, Vienna. [B IX a 432] [online] Avialiable at: https://mapire.eu/en/map/firstsurvey-bukovina$2 /$ ?bbox $=2866711.4052038062 \% 2 \mathrm{C} 6090672.0765940165 \% 2 \mathrm{C} 2890710.6904279124 \% 2 \mathrm{C} 6098333.460544$ 25 [Accessed 1 October 2020]

Czernowitz, 1823. Map of the city of Czernovitz, 1823. Austrian War Archive, Vienna. GIh 131 [online] Avialiable at: https://uma.lvivcenter.org/en/maps/34429) [Accessed 1 October 2020]

Czernowitz, 1830. City of Czernowitz. 1830. Austrian War Archive, Vienna. GIh 131-6 [online] Avialiable at: https://uma.lvivcenter.org/en/maps/34430 [Accessed 1 October 2020]

Czernowitz, 1880. Map of Czernowitz. Expanded in 1880 (Plan von Czernowitz. Ergänzt im Jahre 1880) Austrian War Archive, Vienna. GIh 133. [online] Avialiable at: https://uma.lvivcenter.org/en/maps/34432 [Accessed 1 October 2020]

Vechers'kyy, 2008. Vechers'kyy, V. V., ed., Historical and urban research of Chernivtsi. Kyiv: 2008.

Kayndl', 2005. Kayndl', R. F., History of Chernivtsi from ancient times to the present. Translate from Deutsch by V. YU. Ivanyuk. Chernivtsi: Zelena Bukovyna, 2005.

Kolosok, 2003. Kolosok B., Urban heritage of Chernivtsi. Arkhitekturna spadshchyna Chernivtsiv avstriys'koyi doby. (materialy konferentsiyi $1-4$ zhovtnya 2001 r). Chernivtsi: Zoloti lytavry, 2003.

Mohytych, 2003. Mohytych, R., Urban development of Chernivtsi in the 14th-19th centuries. Shlyakhy okhorony urbanistychnoho seredovyshcha mista. Arkhitekturna spadshchyna Chernivtsiv avstriys'koyi doby. (materialy konferentsiyi 1 - 4 zhovtnya2001 r). Chernivtsi: Zoloti lytavry, 2003.

Tymoshchuk, 1968. Tymoshchuk, B., Dorohamy predkiv. Uzhhorod, 1968.

Chernivtsi. 2019. [online] Avialiable at: https://uk.wikipedia.org/wiki/\%D0\%A7\% D0\%B5\%D1\%80\%D0\%BD\%D1\%96\%D0\%B2\%D1\%86\%D1\%96 [Accessed 1 October 2020]

Nomination, 2008. The residence of Bukovyna and Dalmatia Metropolitans in Chernivtsi. Nomination by the government of Ukraine for inscription. The residence of Bukovyna and Dalmatia Metropolitans in Chernivtsi on the World Heritage List 2008. Prepared by government of Ukraine, state and local authorities and the academic council of Yurij Fedkovych National University. [online] Avialiable at: https://whc.unesco.org/uploads/nominations/1330.pdf [Accessed 1 October 2020].

Galicia and Bucovina, 1861. Galicia and Bucovina (1861-1864) - Second military survey of the Habsburg Empire [online] Avialiable at: <https://mapire.eu/en/map/secondsurveygalicia/?layers $=11 \&$ bbox $=2650396.6280172416 \% 2 \mathrm{C} 6410880.850074071 \% 2 \mathrm{C} 2698743.0484076156 \% 2 \mathrm{C} 6$ 426168.255731106> [Accessed 1 October 2020]

Mykola Bevz

Head of Department of Architecture and Conservation, L'viv Polytechnic National University, Professor, Department of Built Conservation, Lublin University of Technology email: bevzmist@polynet.lviv.ua 


\title{
FORTIFICATION OBIECTS AND STREET NETWORK DEVELOPMENT IN THE HISTORICAL PART OF CHERNIVTSI CITY IN THE $18^{\text {th }}-20^{\text {th }}$ CENTURIES
}

\author{
(C) Bevz M., Kyshlyaruk O., 2020
}

Abstract. Formation and development of the central part of Chernivtsi is a long historical process. The settlement, which emerged in the XIV century, underwent major urban transformations that took place during the XVIII-XX centuries. They became an important period of creation of the renewed structure plan of the city area which is still in operation. The historical city centre has been changing its structure, size, functional organization during a long time. The objective of the research is to study and compare the main parameters and characteristics of the city at certain historical stages by analysing the development of its transport network. The purpose of the article is to review and analyse available cartographic materials and study the street network development in the historical part of the city in the late XVIII - XX centuries. The article highlights the factors that played an important role in the formation and development of Chernivtsi city centre, in particular, strengthening and expansion of economic ties. According to the findings, discovery of new trade routes became a decisive factor that influenced the development of Chernivtsi, determined the city structure and directions of the main streets. Other important factors include natural conditions and local terrain, social economic and administrative impact. Studies have shown that the historical centre of Chernivtsi evolved according to the existing structure plan. Analysis of cartographic materials and historical sources allows to characterize the basic principles of urban development. Expansion of the street network and squares, as well as trends in the planning of residential areas provide an opportunity to assess their nature, scale and size. Topographical maps enabled us to devise comparative schemes of urban development and evolution of city boundaries throughout the studied period. The city center moved gradually to new areas in the south-western direction. This feature of the city development provides important materials for urban study. This work can be primarily aimed at studying the urban planning structure, defense lines, public spaces, etc. The city developed in an extensive way, pushing the boundaries of the city center, creating new parallel urban complexes with new central squares. The most difficult task for scientists today is to localize these boundaries for different stages.

The next difficult task is to find out old defense systems existed in the different parts of the city in the past. A completely unresolved question is how defense complexes influenced the development of the planning structure. The study allowed to highlight the prerequisites for major urban transformations in the historical part of Chernivtsi in the XVIII - XX centuries.

Key words: structure plan, street network, planning framework, historical centre, fortifications, Chernivtsi city. 